\title{
Para meu pai
}

Leonor Scliar-Cabral ${ }^{*}$

Fumaça nos meus olhos, nevoeiro, cortinas de infortúnio tão pressagas a perturbarem os reflexos d'água espelhando o balouço das palmeiras.

Da Oswaldo Aranha, amantes foragidos, chegávamos ao lago por atalhos: cardumes cobiçavam as migalhas jogadas por soldados distraídos, indiferentes à futura Ofélia a boiar entre choupos e camélias em busca do perdão na correnteza.

A vela onde está por ser acesa? Talvez a menorá de quem espera se acenda tarda na terceira esfera.

*Leonor Scliar-Cabral é poeta, professora de literatura e tradutora. Autora de, entre outros títulos, Memórias de Sefarad, de 1994, e O sol caía no Guaíba, de 2006. 